\title{
Occult hepatitis B infection in Egyptian health care workers
}

\author{
Reem Elmaghloub ', Ashraf Elbahrawy 2, Gamal El Didamony', Alaa Hashim ${ }^{3}$, Mohamed H. Morsy ${ }^{4}$, Osamah \\ Hantour ${ }^{5}$, Abdelateef Hantour ${ }^{5}$ and Mohamed Abdelbaseer ${ }^{6}$
}

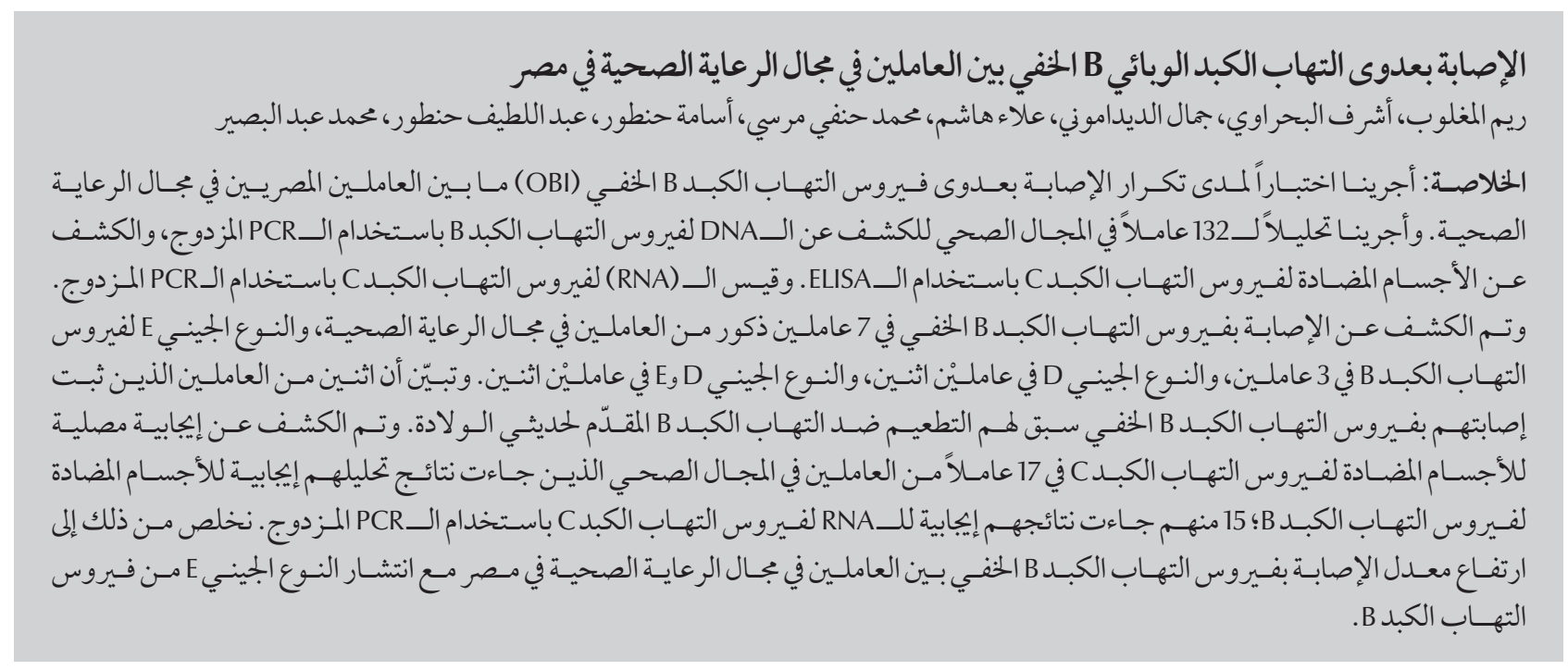

ABSTRACT We tested the frequency of occult hepatitis B infection (OBI) among Egyptian healthcare workers (HCWs). We tested $132 \mathrm{HCWs}$ for hepatitis B virus (HBV) DNA by nested polymerase chain reaction (PCR), and hepatitis C virus antibody (anti-HCV) by ELISA. HCV RNA was measured by nested PCR in anti-HCV-positive HCWs. HBV-DNA-positive HCWs were subjected to HBV genotyping. We included $132 \mathrm{HCWs}$ who were negative for hepatitis B surface antigen and positive for hepatitis B core antibody (anti-HBc). OBI was detected in 7 male HCWs, and HBV E genotype was detected in 3, HBV D in 2 and HBV D and E in 2. Two OBI-positive HCWs had a history of neonatal hepatitis B vaccination. Anti-HCV seropositivity was detected in $17 \mathrm{HCW}$ sho were positive for anti-HBc; 15 of whom were positive for HCV RNA by nested PCR. HCV infection was confirmed by anti-HCV and HCV RNA in 1 of $7 \mathrm{HCW}$ s with $\mathrm{OBI}$. In conclusion, Egyptian HCWs have a significant rate of $\mathrm{OBI}$ and $\mathrm{HBV}$ E genotype is prevalent.

\section{Hépatite B occulte chez des agents de soins de santé égyptiens}

RÉSUMÉ Nous avons étudié la fréquence de l'hépatite B occulte chez des agents de soins de santé égyptiens. Nous avons examiné 132 agents de santé à la recherche d'ADN du virus de l'hépatite B (VHB) au moyen de l'amplification en chaîne par polymérase (PCR) nichée et de l'anticorps du virus de l'hépatite C (anti-VHC) par la méthode ELISA. L'ARN du VHC a été mesurée par PCR nichée chez des agents de santé positifs pour l'anticorps anti-VHC. Les agents de santé positifs pour l'ADN du VHB ont été soumis au génotypage du VHB. Nous avons inclus 132 agents de soins qui étaient négatifs pour l'antigène de surface de l'hépatite B et positifs pour l'anticorps antinucléaire de I'hépatite B (Anti-HBc). Une hépatite B occulte a été détectée chez 7 agents de santé de sexe masculin, et le VHB de génotype $\mathrm{E}$ a été détecté chez trois agents, le VHB de génotype $\mathrm{D}$ chez 2 agents, et le VHB de génotype $\mathrm{D}$ et $\mathrm{E}$ chez 2 agents. Deux des agents positifs pour l'hépatite B occulte avaient été vaccinés durant la période néonatale. Une séropositivité anti-VHC a été détectée chez 17 agents de santé qui étaient positifs pour l'anticorps anti-HBc, dont 15 étaient positifs pour l'ARN du VHC par PCR nichée. L'infection à VHC a été confirmée par l'anti-VHC et par I'ARN du VHC chez 1 agent sur 7 atteints d'hépatite B occulte. En conclusion, les agents de santé égyptiens ont un taux d'hépatite B occulte significatif et le génotype E du VHB est prévalent.

${ }^{1}$ Department of Botany and Microbiology, Faculty of Science, Al-Zagazig University, Al-Zagazig, Egypt. ${ }^{2}$ Department of Internal Medicine, Al-Azhar School of Medicine, Al-Azhar University, Cairo, Egypt (Correspondence to: A. Elbahrawy: bahrawy3@hotmail.com). ${ }^{3}$ Department of Clinical Pathology, Al-Azhar School of Medicine, Al-Azhar University, Asyut, Egypt. ${ }^{4}$ Department of Clinical Pathology, Al-Azhar School of Medicine, AlAzhar University, Cairo, Egypt. ${ }^{5}$ Al-Azhar School of Medicine, Al-Azhar University, Cairo, Egypt. ${ }^{6}$ Department of Microbiology, Faculty of Science Al-Azhar University, Cairo, Egypt.

Received: 20/07/16; accepted: 25/10/16 


\section{Introduction}

Egyptian healthcare workers (HCWs) are at increased risk of infection with bloodborne pathogens. Countrywide baseline assessment in 2001 revealed that government and private hospitals had no occupational safety programmes. A 2002 survey of Egyptian HCWs revealed unsafe practices in the use and disposal of sharps and reported that HCWs were frequently exposed to needle stick injuries. This problem is aggravated by low hepatitis B vaccination coverage, which was only $14 \%$ among Egyptian HCWs (1).

Occult hepatitis B infection (OBI) is marked by the presence of hepatitis $B$ virus (HBV) nucleic acid in serum and/ or liver tissue, with hepatitis B surface antigen (HBsAg) seronegativity. The worldwide prevalence of $\mathrm{OBI}$ ranges from 1 to $95 \%$ (2), depending on HBV endemicity, the method of detection of HBV DNA, and the studied risk group. The frequency of OBI among HCWs ranges from 0 to $11 \%(3-6)$.

Egypt had a high prevalence of hepatitis $\mathrm{C}$ virus $(\mathrm{HCV})$ and intermediate endemicity of $\mathrm{HBV}$ infection. The prevalence of HBsAg and HCV antibody (anti-HCV) among Egyptian HCWs is $1.5 \%$ and $8-16.6 \%$, respectively (7, $8)$. High frequencies of OBI have been detected among different high-risk populations in Egypt, including blood donors, and patients with chronic hepatitis C, haemodialysis, polytransfusion and haematological and solid malignancies (9). HBV genotypes B-D have been detected among Egyptian OBI patients $(9,10)$. In this study we aimed to clarify the overall prevalence of $\mathrm{OBI}$ among Egyptian HCWs.

\section{Methods}

\section{Study population}

This was a descriptive cross-sectional study conducted between June 2014 and April 2015 among workers of governmental $(n=69)$ and nongovernmental $(n=63)$ hospitals in Tanta City, Egypt. These included tertiary $(n=25)$, secondary $(n=92)$ and primary care $(n$ $=15$ ) hospitals. All employed staff were invited to participate in the study during an 8-week period. Medical and nursing students on clinical placements were not considered as hospital staff and hence were ineligible for recruitment.

\section{Study recruitment}

HCWs were recruited on the basis of accepting study enrolment without any random selection. All HCWs completed the study questionnaire and provided a blood sample for $\mathrm{HBsAg}$ testing. Among $556 \mathrm{HCWs}$ negative for HBsAg, 132 (23.7\%) were positive for hepatitis B core antibody (anti-HBc) and included in the study. A single study-trained researcher collected data from all study participants. Data on personal demographics, and risk factors for bloodborne infections were collected.

\section{Blood sampling}

For each study participant, $5 \mathrm{ml}$ of venous blood was collected. Each sample was centrifuged within 6 hours of collection, divided into 2 serum aliquots and stored at $-21^{\circ} \mathrm{C}$ for subsequent testing.

\section{Antiviral serology}

HBsAg and anti-HBc were tested by third-generation ELISA. Anti-HBcpositive samples were retested and only samples that were positive on both occasions were considered positive. HBsAg-negative and anti-HBc-positive HCWs $(n=132)$ were further tested for anti-HCV by third-generation ELISA.

\section{Detection of HBV DNA by polymerase chain reaction (PCR)}

HBsAg-negative and anti- $\mathrm{HBc}$ positive samples $(n=132)$ were tested for HBV DNA using nested PCR (core fragment), as described previously (11). DNA was extracted from patients' sera using QIAamp DNA Mini Kit
(Qiagen GmbH, Hilden, Germany). HBV DNA was amplified using two different primer pairs (first set: forward 5'-GTCTGCGGCGTTTATC-3'; and reverse 5'ACAGTGGGGGAAAGC-3'; second set: forward 5'-TGCCCGTTTGTCCTCTA-3' and reverse 5'-AGAAACGGRCTGAGGC-3'). Samples from all positive cases were retested to confirm positive results.

\section{HBV genotyping}

Seven serum samples that were positive for HBV DNA by nested PCR underwent $\mathrm{HBV}$ genotyping. The PCR was conducted as described previously (12) using the primer sequences shown in Table 1.

\section{HCV RNA isolation and nested PCR}

Anti-HCV-positive samples $(n=17)$ were tested for HCV RNA by nested PCR. Viral RNA was extracted using the QIAamp Viral RNA Mini Kit (Qiagen). The primer sequences were as follows: forward 5'-CGCGCGACTAGGAAGACTTC-3' and reverse 5'-ACCCTCGTTTCCGTACAGAG-3'.

\section{Ethics}

All procedures followed the regulations of Al-Azhar University Ethics Committee. Informed consent was given by all HCWs participating in the study. Participants were informed of the potential risks and benefits of the study before enrolment. Participants' data were anonymized to optimize confidentiality and privacy, with laboratory data collected and stored only by study number in secure systems. The key record identifying the participant was kept confidential and not made available, except to the principal investigator responsible for dissemination of results to individual participants. Following testing, the principal investigator provided participants with test results on an individual basis. 


\begin{tabular}{|c|c|}
\hline Primer & Sequence $^{\text {a }}$ (position, specificity and polarity) \\
\hline \multicolumn{2}{|c|}{ First PCR } \\
\hline $\mathrm{P} 1^{\mathrm{b}}$ & 5'-TCA CCA TAT TCT TGG GAA CAA GA-3' (nt 2823-2845, universal, sense) \\
\hline S1-2 & 5'-CGA ACC ACT GAA CAA ATG GC-3' (nt 685-704, universal, antisense) \\
\hline \multicolumn{2}{|c|}{ Second PCR } \\
\hline \multicolumn{2}{|l|}{$\operatorname{Mix} A$} \\
\hline B2 & 5'-GGC TCM AGT TCM GGA ACA GT-3' (nt 67-86, genotypes A-E specific, sense) \\
\hline BA1R & 5'-CAG GTT GGT GAG TGA CTG GAG A-3' (nt 324-345, genotype B specific, antisense) \\
\hline BB1R & 5'-CAG GTT GGT GAG TGA CTG GAG A-3' (nt 324-345, genotype B specific, antisense) \\
\hline $\mathrm{BC1R}$ & 5'-GGT CCT AGG AAT CCT GAT GTT G-3' (nt 165-186, genotype C specific, antisense) \\
\hline \multicolumn{2}{|l|}{ Mix B } \\
\hline BD1 & 5'-GCC AAC AAG GTA GGA GCT-3' (nt 2979-2996, genotype D specific, sense) \\
\hline BE1 & 5'-CAC CAG AAA TCC AGA TTG GGA CCA-3' (nt 2955-2978, genotype E specific, sense) \\
\hline BF1 & 5'-GYT ACG GTC CAG GGT TAC CA-3' (nt 3032-3051, genotype F specific, sense) \\
\hline B2R & 5'-GGA GGC GGA TYT GCT GGC AA-3' (nt 3078-3097, genotypes D-F specific, antisense) \\
\hline
\end{tabular}

${ }^{a} M$ represents $A$ or a $C ; Y$ represents $C$ or $T$.

${ }^{b}$ Sequence for primer P1 was determined by Lindh et al. (35).

$n t=$ nucleotide $; P C R=$ polymerase chain reaction .

\section{Statistical analysis}

SPSS version 17 was used for statistical analysis. Differences in frequency between groups were compared with the $\chi^{2}$ test or Fisher's exact test. $P \leq 0.05$ was considered significant.

\section{Results}

\section{Characteristics of HCWs}

We enrolled 132 HCWs who were HBsAg negative and anti-HBc positive from governmental $(n=69)$ and nongovernmental $(n=63)$ hospitals in the Nile Delta. There were 67 (50.8\%) women and 65 (49.2\%) men, with a mean (standard deviation) age of 37.4 (11.9) years (range 16-64 years). Fifty-nine (44.7\%) HCWs provided direct care to patients: 55 (41.7\%) nurses, 3 (2.2\%) laboratory technicians and $1(0.8 \%)$ physician. Seventy-three (55.3\%) HCWs were non-healthcare providers (HCPs): 35 (26.5\%) ward workers, 17 (12.9\%) administrative officers, 11 (8.3\%) security personnel, 9 (6.8\%) drivers and $1(0.8 \%)$ cook. The mean duration of healthcare work was 12.63 (7.93) years. Fifteen (11.4\%), 8 (6.1\%), $2(1.5 \%)$ and $1(0.8 \%)$ of the
HCWs had a history of hepatitis B vaccination, prior surgery, type 2 diabetes mellitus and parenteral antischistosomal therapy (PAT), respectively. None of the HCWs had a history of blood transfusion or haemodialysis. Seventeen $(12.88 \%) \mathrm{HCW}$ sere positive for anti-HCV and 115 (87.12\%) were negative. Fifteen (88.23\%) of these 17 were also positive for HCV RNA by nested PCR.

\section{OBI among HCWs}

OBI was detected in 7 (5.3\%) of 132 anti-HBc-positive HCWs. All were male with a mean age of 35.85 (13.64) years (range 19-58 years); 4 worked in governmental hospitals and 3 in nongovernmental hospitals; and 3 were nurses and 4 were non-HCPs. The mean duration of healthcare work was 13.8 (7.69) years (range 8-27 years).

None of the HCWs with OBI had a history of surgery, PAT, type 2 diabetes (Table 2), blood transfusion or haemodialysis. Male sex was associated with OBI in our HCWs $(P<0.05)$ but older age was not associated with increased risk of OBI $(P>0.05)$ (Table 2).

Three of the $7 \mathrm{HCW}$ sith OBI had HBV genotype E, and 2 each had
HBV genotype D or genotypes D and E. HBV genotype $\mathrm{E}$ was detected in 1 HCW from a governmental hospital and 2 from nongovernmental hospitals. All OBI HCWs with HBV genotype $\mathrm{E}$ alone were non-HCPs. HBV genotype $\mathrm{D}$ was detected in 2 nurses working at governmental hospitals.

Two of the 7 HCWs with OBI had a history of neonatal hepatitis B vaccination, and both were negative for $\mathrm{HCV}$ infection. One of them had HBV genotype $\mathrm{E}$ and the other genotype $\mathrm{D}$.

$\mathrm{HCV}$ infection was confirmed by both anti-HCV and HCVRNA in 1 of 7 HCWs with OBI.

\section{Discussion}

We found that $5.3 \%$ of HCWs with anti-HBc seropositivity had OBI. Male sex was associated with risk of $\mathrm{OBI}$ in HCWs, yet old age and HCV infection were not. OBI in HCWs was related to HBV genotypes D, E or co-infection with both genotypes. Two HCWs with OBI had prior history of infantile HBV vaccination.

OBI is reported in both upper and lower Egypt. Egyptian patients with 


\begin{tabular}{|c|c|c|c|c|}
\hline & \multicolumn{2}{|c|}{ Positive } & \multirow[t]{2}{*}{$x^{2}$} & \multirow[t]{2}{*}{$P$ value } \\
\hline & $n$ & $\%$ & & \\
\hline \multicolumn{5}{|l|}{ Age (yr) } \\
\hline$\leq 30$ & 2 & 28.6 & 0.010 & 0.918 \\
\hline$\geq 30$ & 5 & 71.4 & & \\
\hline \multicolumn{5}{|l|}{ Sex } \\
\hline Female & 0 & 0.0 & 7.619 & $0.006^{*}$ \\
\hline Male & 7 & 100.0 & & \\
\hline \multicolumn{5}{|l|}{ Prior surgery } \\
\hline No & 7 & 100.0 & 0.477 & 0.490 \\
\hline Yes & 0 & 0.0 & & \\
\hline Non-HCPs & 4 & 57.1 & 0.004 & 0.953 \\
\hline HCPs & 3 & 42.9 & & \\
\hline Nongovernmental HCWs & 3 & 42.9 & 0.070 & 0.791 \\
\hline Governmental HCWs & 4 & 57.1 & & \\
\hline \multicolumn{5}{|l|}{ Diabetes mellitus } \\
\hline No & 7 & 100.0 & 0.114 & 0.736 \\
\hline Yes & 0 & 0.0 & & \\
\hline \multicolumn{5}{|l|}{$P A T$} \\
\hline No & 7 & 100.0 & 0.056 & 0.812 \\
\hline Yes & 0 & 0.0 & & \\
\hline \multicolumn{5}{|l|}{ Anti-HCV } \\
\hline Nonreactive & 6 & 85.7 & 0.013 & 0.909 \\
\hline Reactive & 1 & 14.3 & & \\
\hline
\end{tabular}

*Significant result $(P \leq 0.05)$

$H C P=$ healthcare provider; $H C V=$ hepatitis $C$ virus; $H C W=$ healthcare worker; $O B I=$ occult hepatitis $B$ infection; $P A T=$ parenteral antischistosomal therapy.

chronic hepatitis $\mathrm{C}$ have a high prevalence of $\mathrm{OBI}$ where the presence of $\mathrm{OBI}$ is associated with more progressive liver disease. Reactivation of OBI after chemotherapy has also been reported in Egyptian patients. Anti-HBc has ben identified as a good marker for OBI among different high-risk groups in Egypt (9).

HCWs with OBI may pass undetected and be unaware of their status, placing their patients at risk of infection. There are scarce data on the prevalence of OBI in HCWs worldwide. In the majority of reported studies, the molecular tests were carried out on anti-HBcpositive samples (13). The main finding of our study was that $5.3 \%$ of Egyptian HCWs positive for anti-HBc had OBI. This rate is comparable to that reported from India (5\%) (14), Poland (4\%) (15) and South Africa (6.6\%) (16) but markedly lower than the $11 \%$ reported by Chiarakul et al. from Thailand (3). The higher OBI rate in the latter study
(21). Although the ultimate mechanism regulating this difference is not well known, the greater persistence of chronic HBV infection, the low level of anti-HBs production, and greater nuclear integration of HBV DNA in men may explain the male predominance of OBI in our HCWs.

Few studies have examined the frequency of HBV genotypes among Egyptians with OBI. In the current study, we detected the presence of genotype $\mathrm{E}$ and coexistence of genotypes D and $\mathrm{E}$ among HCWs with OBI. $\mathrm{HBV}$ genotype $\mathrm{E}$ is considered to exist mainly in East, Central and West Africa. The fact that many students from these countries are studying at Al-Azhar University suggests transmission of HBV genotype $\mathrm{E}$ from these students to Egyptian HCWs. The detection of HBV genotype E among Egyptian HCWs with $\mathrm{OBI}$ and its absence among other Egyptian risk groups may support hospital-acquired HBV infection among HCWs in our study.

As HBV and HCV share many risk factors and transmission routes, the detection of HCV infection among anti-HBc-positive HCWs with or without $\mathrm{OBI}$ is not surprising. El-Sherif et al. (23) showed that, among HBsAgnegative patients, the number with PAT is significantly higher in anti-HBc-positive, HCV-positive patients, compared with anti-HBc-negative, $\mathrm{HCV}$-positive patients. They concluded that PAT transmits both $\mathrm{HCV}$ and $\mathrm{HBV}$ among many Egyptians.

OBI detection in HCWs may have an impact in several clinical contexts. The possible transmission of the infection from HCWs to patients is an important issue. Compared to overt HBV infection, the routes of transmission of OBI have been studied less. OBI transmission has been reported after blood transfusion, liver transfusion (24) and intrauterine infection in pregnant women with OBI (25). Moreover OBI is transmitted by close contact and manifests clinically (26), which suggests the 
healthcare setting as a risk environment for OBI horizontal transmission. The contribution of $\mathrm{OBI}$ to liver disease progression (26), development of HCC (26), and the risk of HBV reactivation (27) is also important, and suggests screening and treatment of HCWs with OBI. Another relevant factor is the poor response of HCWs with OBI to hepatitis $B$ vaccination. The absence of an immune response after hepatitis $B$ vaccination has been reported among $5-20 \%$ of HCWs (28-30). This was attributed to host immune dysfunction $(31,32)$ and viral factors. Indeed, OBI has been documented in HCWs who did not respond to hepatitis B vaccination. This suggests that HCWs with inadequate anti-HBs levels after hepatitis $B$ vaccination should be tested for the presence of OBI by sensitive molecular tests (5).

Forprevention of HBV transmission from HCWs to patients, the US Centers for Disease Control and Prevention recommend that HCWs who perform exposure-prone procedures, and who do not have serological evidence of immunity to HBV from vaccination or previous infection, should know their HBsAg status and, if that is positive, should also know their hepatitis B e antigen status. The detection of $\mathrm{OBI}$ in HCWs infers that HBsAg may not be an effective indicator of HBV status and suggests nucleic acid testing.

Hepatitis B vaccination is the most effective method for preventing HBV infection. Yet, the protective anti-HBs level decreases over time after neonatal vaccination (33). Although it is generally believed that neonatal hepatitis B vaccination is protective for $15-20$ years, and booster vaccinations not required, OBI has been detected in vaccinated people with a mean age of 19-21 years (34). We detected OBI in 2 of 15 HCWs with a history of neonatal hepatitis B vaccination. We recommend that HCWs with such a history should be tested for anti-HBs levels and receive booster vaccination. HCWs with $\mathrm{OBI}$ had prolonged duration of healthcare work [13.8 (7.69) years] compared with those without OBI [12.58 (7.97) years], which supports the waning of protective anti-HBs levels over time.

In conclusion, there was a high prevalence of OBI among Egyptian HCWs who were positive for anti-HBc. HCWs with $\mathrm{OBI}$ were mainly male and HBV genotype $E$ was the most prevalent. OBI and $\mathrm{HCV}$ co-infection were detected and OBI was detected among HCWs with neonatal hepatitis $\mathrm{B}$ vaccination. Anti-HBc and/or nucleic acid testing of Egyptian HCWs is recommended to detect and prevent OBI in the healthcare setting. Routine prior hepatitis B vaccination of HCWs and strict infection control measures are mandatory to protect against $\mathrm{OBI}$.

Funding: None.

Competing interests: None declared.

\section{References}

1. Talaat M, Kandeel A, El-Shoubary W, Bodenschatz C, Khairy I, Oun S, et al. Occupational exposure to needlestick injuries and hepatitis $B$ vaccination coverage among health care workers in Egypt. Am J Infect Control. 2003 Dec;31(8):469-74. PMID:14647109

2. Gutiérrez-García ML, Fernandez-Rodriguez CM, Lledo-Navarro JL, Buhigas-Garcia I. Prevalence of occult hepatitis B virus infection. World J Gastroenterol. 2011 Mar 28;17(12):1538-42. PMID:21472117

3. Chiarakul S. Eunumjitkul K, Vorapimol AR, Kaewkungwal J, Chimparlee N, Poovorawan Y. Response of health care workers with isolated antibody to hepatitis B core antigen to hepatitis B vaccine. Southeast Asian J Trop Med Public Health. 2011 Jul;42(4):831-8. PMID:22299465

4. Slusarczyk J. Małkowski P, Bobilewicz D, Juszczyk G. Crosssectional, anonymous screening for asymptomatic HCV infection, immunity to HBV, and occult HBV infection among health care workers in Warsaw, Poland. Przegl Epidemiol. 2012;66(3):445-51. PMID:23230715

5. Yen YH. Chen $\mathrm{CH}$, Wang JH, Lee CM, Changchien CS, Lu SN. Study of hepatitis B (HB) vaccine non-responsiveness among health care workers from an endemic area (Taiwan). Liver Int. 2005 Dec;25(6):1162-8. PMID:16343067

6. Shim J, Kim KY, Kim BH, Chun H, Lee MS, Hwangbo Y, et al. Anti-hepatitis B core antibody is not required for prevaccination screening in healthcare workers. Vaccine. $2011 \mathrm{Feb}$ 11;29(8):1721-6. PMID:21147128

7. Abdelwahab S, Rewisha E, Hashem M, Sobhy M, Galal I, Allam WR, et al. Risk factors for hepatitis $C$ virus infection among Egyptian healthcare workers in a national liver diseases refer- ral centre. Trans R Soc Trop Med Hyg. 2012 Feb;106(2):98-103. PMID:22197011

8. Okasha O, Munier A, Delarocque-Astagneau E, El Houssinie $M$, Rafik M, Bassim H, et al. Hepatitis C virus infection and risk factors in health-care workers at Ain Shams University Hospitals, Cairo, Egypt. East Mediterr Health J. 2015 May19;21(3):199212. PMID:26074220

9. Elbahrawy A, Alaboudy A, El Moghazy W, Elwassief A, Alashker A, Abdallah AM. Occult hepatitis B virus infection in Egypt. World J Hepatol. 2015 Jun28;7(12):1671-8. PMID:26140086

10. Esmail MA, Mahdi WK, Khairy RM, Abdalla NH. Genotyping of occult hepatitis B virus infection in Egyptian hemodialysis patients without hepatitis C virus infection. J Infect Public Health. 2016 Jul-Aug;9(4):452-7. PMID:2677809

11. Kaneko S. Feinstone SM, Miller RH. Rapid and sensitive method for the detection of serum hepatitis B virus DNA using the polymerase chain reaction technique. J Clin Microbiol. 1989 Sep;27(9):1930-3. PMID:2778059

12. Naito H. Hayashi S, Abe K. Rapid and specific genotyping system for type-specific primers major genotypes by PCR using hepatitis B virus corresponding to six. J Clin Microbiol. 2001 Jan;39(1):362-4. PMID:11136801

13. Alavian SM. Jazayeri SM. Occult Hepatitis B infection (OBI) in vaccinated groups, a metanalysis. Arch Med Lab Sci.2015;1(2):74-83 (journals.sbmu.ac.ir/archives/article/ download/10296/9598).

14. Sukriti, Pati NT, Sethi A, Agrawal K, Kumar GT, Kumar M, et al. Low levels of awareness, vaccine coverage, and the need for boosters among health care workers in tertiary care hospitals 
in India. J Gastroenterol Hepatol. 2008 Nov;23(11):1710-5. PMID:18761556

15. Slusarczyk J. Malkowski P, Bobilewicz D, Juszczyk G. Crosssectional, anonymous screening for asymptomatic HCV infection, immunity to HBV, and occult HBV infection among health care workers in Warsaw, Poland. Przegl Epidemiol. 2012;66(3):445-51.

16. Sondlane TH, Mawela L, Razwiedani LL, Selabe SG, Lebelo RL, Rakgole JN, et al. High prevalence of active and occult hepatitis B virus infections in healthcare workers from two provinces of South Africa. Vaccine. 2016Jul19;34(33):3835-9. PMID:27265453

17. Antar W. El-Shokry MH, Abd El Hamid WA, Helmy MF. Significance of detecting anti-HBc among Egyptian male blood donors negative for HBsAg. Transfus Med. 2010 Dec;20(6):409-13. PMID:20573069

18. El-Sherif AM. Abou-Shady MA, Al-Hiatmy MA, Al-Bahrawy AM, Motawea EA. Screening for hepatitis B virus infection in Egyptian blood donors negative for hepatitis B surface antigen. Hepatol Int. 2007 Dec;1(4):469-70. PMID:19669344

19. Said ZN, Sayed MH, Salama II, Aboel-Magd EK, Mahmoud MH, Setouhy ME, et al. Occult hepatitis B virus infection among Egyptian blood donors. World J Hepatol. 2013 Feb 27;5(2):6473. PMID:23646231

20. Chiarakul S, Eunumjitkul K, Vuttiopas S, Vorapimol AR, Kaewkungwal J, Poovorawan Y. Seroprevalence and risk factors of hepatitis B virus infection among health care workers at the Institute of Neurology. J Med Assoc Thai. 2007 Aug;90(8):1536-45. PMID:17926982

21. Chu CM. Liaw Y-F, Sheen I-S, Lin D-Y, Huan M-J. Sex difference in chronic hepatitis B virus infection: an appraisal based on the status of hepatitis B e antigen and antibody. Hepatology. 1983 Nov-Dec;3(6):947-50. PMID:6313507

22. Chiaramonte $M$, Trivello R, Renzulli G, Zampieri L, Fanecco A, Floreani A, Naccarato R. Hepatitis B virus infection in prisons. A seroepidemiological survey in prisoners and attending staff. J Hyg (Lond). 1982 Aug;89(1):53-8. PMID:7097002

23. El-Sherif A. Abou-Shady M, Abou-Zeid H, Elwassief A, Elbahrawy A, Ueda Y, Chiba T, Hosney AM. Antibody to hepatitis B core antigen as a screening test for occult hepatitis B virus infection in Egyptian chronic hepatitis C patients. J Gastroenterol. 2009;44(4):359-64. PMID:19271112

24. Raimondo G. Caccamo G, Filomia R, Pollicino T. Occult HBV infection. Semin Immunopathol. 2013 Jan;35(1):39-52. PMID:22829332

25. Gui QD, Yue YF, Li SH, Zhang F. [Study on intrauterine infection of hepatitis B virus in pregnant women with hepatitis B surface antigen and hepatitis B e antigen negative]. Zhonghua Fu Chan Ke Za Zhi. 2005 Feb;40(2):99-102 (in Chinese). PMID:15840288

26. Hu L-P, Liu D-P, Chen Q-Y, Harrison TJ, He X, Wang X-Y, et al. Occult HBV infection may be transmitted through close contact and manifest as an overt infection. PLoS One. 2015 Oct 12;10(10):e0138552. PMID:26457811

27. Raimondo G. Pollicino T, Romanò L, Zanetti AR. A 2010 update on occult hepatitis B infection. Pathol Biol (Paris). 2010 Aug;58(4):254-7. PMID:20303674

28. Di Bisceglie AM. Lok AS, Martin P, Terrault N, Perrillo RP, Hoofnagle JH. Recent US Food and Drug Administration warnings on hepatitis B reactivation with immune-suppressing and anticancer drugs: just the tip of the iceberg? Hepatology. 2015 Feb;61(2):703-11. PMID:25412906

29. Saberifiroozi M. Gholamzadeh S, Serati AR. The long-term immunity among health care workers vaccinated against hepatitis $B$ virus in a large referral hospital in southern Iran. Arch Iran Med. 2006 Jul;9(3):204-7. PMID:16859051

30. Alavian SM. Mansouri S, Abouzari M, Assari S, Bonab MS, Miri SM. Long-term efficacy of hepatitis B vaccination in healthcare workers of Oil Company Hospital, Tehran, Iran (19892005). Eur J Gastroenterol Hepatol. 2008 Feb;20(2):131-4. PMID:18188034

31. Mansour-Ghanaei F, Fallah MD, Jafarshad R, Joukar F, Arami $M$, Ale-ESmaeil $A$ et al. The immunologic response to antihepatitis B vaccination among medical students of Guilan University of Medical Sciences, Guilan, Iran. Hepat Month. 2006 Jun;6(2):63-6 (http://hepatmon.com/610.fulltext)

32. Valats JC, Tuaillon E, Funakoshi N, Hoa D, Brabet MC, Bolloré $\mathrm{K}$ et al. Investigation of memory B cell responses to hepatitis B surface antigen in health care workers considered as nonresponders to vaccination. Vaccine. 2010 Sep 7;28(39):6411-6. PMID:20682363

33. Elrashidy H, Elbahrawy A, El-Didamony G, Mostafa M, George NM, Elwassief A, et al. Antibody levels against hepatitis B virus after hepatitis B vaccination in Egyptian diabetic children and adolescents. Hum Vaccin Immunother. 2013 Sep;9(9):2002-6. PMID:23787761

34. Xu L, Wei Y, Chen T, Lu J, Zhu CL, Ni Z, et al. Occult HBV infection in anti-HBs-positive young adults after neonatal $\mathrm{HB}$ vaccination. Vaccine. 2010 Aug 23;28(37):5986-92. PMID:20637763

35. Lindh M, Gonzalez JE, Norkrans G, Horal P. Genotyping of hepatitis B virus by restriction pattern analysis of a pre-S amplicon. J Virol Methods.1998 Jun;72(2):163-74. PMID:9694324 